\title{
PRUNING THE MONEY-TREE TO ENSURE SUSTAINABLE GROWTH: FACILITATING SUSTAINABLE DEVELOPMENT THROUGH MARKET-BASED INSTRUMENTS
}

\section{AR Paterson}

\section{Introduction}

South Africa's pristine landscapes and natural resources are under significant threat. This is not subject to debate, but what is, is how to implement a regulatory regime to deal effectively with these environmental realities - a challenge complicated by competing socio-economic imperatives; significant capacity and resource constraints and the need to redress past inequalities, efforts to increase access to land and natural resources as well as perceptions that the environment is an elitist concern.

Following South Africa's conversion to a constitutional democracy, the government introduced many significant environmental laws to fulfil its constitutional mandate to take 'reasonable legislative and other measures' to protect the environment. ${ }^{1}$ The majority of these laws adopt the traditional 'command-and-control' approach to environmental management. This approach is based on the assumption that the way to regulate human behaviour impacting on the environment, is to prescribe a range of legislative standards, prohibitions and restrictions and to sanction any person who contravenes them. There is, however, growing realisation, internationally and

* BSocSci LLB (Cape Town) LLM Environmental Law (Cape Town). Senior Lecturer, Institute of Marine and Environmental Law, Faculty of Law, University of Cape Town.

1 S 24(b) of the Constitution of the Republic of South Africa, 1996, hereinafter the Constitution. These laws include, amongst others: National Environmental Management Act 107 of 1998; National Forest Act 84 of 1998; National Water Act 36 of 1998; Marine Living Resources Act 18 of 1998; Genetically Modified Organisms Act 15 of 1997; Minerals and Petroleum Resources Development Act 28 of 2002; National Environmental Management: Protected Areas Act 57 of 2003; National Environmental Management: Biodiversity Act 10 of 2004; and National Environmental Management: Air Quality Act 39 of 2004. 
domestically, that this command-and-control approach is unsatisfactory in many respects. ${ }^{2}$ First, the administration, compliance and enforcement of direct regulation are costly and often undermined by capacity constraints. Secondly, regulations are frequently inflexible in their application and cannot cater for geographical, sectoral or individual specificities. Thirdly, this approach does not encourage or facilitate voluntary initiatives and may restrict technological development as simply enforcing compliance with a minimum regulatory standard which does not foster innovation or encourage people to go beyond regulated performance levels. Finally, it fails to remedy market failure to account for the use of environmental goods and services such as soil, air, water, fauna, flora and broader ecosystems.

Many countries are, therefore, exploring alternative ways of providing for effective environmental management such as: co-opting civil society participation; ${ }^{3}$ creating markets for environmental goods and services; ${ }^{4}$ and using market-based instruments (MBI). The latter form the focus of this article as the National Treasury recently released a draft policy paper for discussion titled A Framework for Considering Market-Based Instruments to Support Environmental Fiscal Reform in South Africa 2006 (Draft Policy Paper). ${ }^{5}$ MBI are defined as the -

...package of policy instruments that seek to correct environmentally-related market failures through the price mechanism...

2 See generally: Stauth and Baskind Resource Economics 39-40; Pearce, Markandya and Barbier Blueprint for a Green Economy 153-172; Westin Understanding Environmental Taxes 3-6; Bruce and Ellis Environmental Taxes; Henderson 1994 SAJELP 50-52; James Environmental Incentives 13; Milne et al (eds) Critical Issues in Environmental Taxation 27-51; Wilkie Natural Capital Incentives 2-4; Paterson 2005 SALJ 182; and Paterson 2005 SAJELP 97.

3 Mechanisms to engage civil society include: mandatory public participation procedures; information disclosure requirements; and the conclusion of voluntary environmental management agreements.

4 Mechanisms to create these markets for environmental goods and services include: introducing tradable permits and rights schemes and using international offset systems.

5 National Treasury Market-Based Instruments: Draft Policy Paper 2006.

6 National Treasury Market-Based Instruments: Draft Policy Paper 2006 at 2. 
- and include: the elimination of perverse subsidies; revenue raising instruments such as environmentally-related taxes, ${ }^{7}$ levies ${ }^{8}$ and user-charges; ${ }^{9}$ deposit-refund systems; and targeted subsidies. This article considers the contents of the Draft Policy Paper, focusing specifically on the various options it proposes for implementing and extending the current use of $\mathrm{MBI}$ as environmental regulatory tools in South Africa.

\section{$2 \quad$ Why the move towards market-based instruments?}

In general, markets provide an efficient means of allocating scarce resources, although not necessarily the most equitable. Prices determined in a competitive environment theoretically create incentives for all participants to maximise the productive use of resources. However, some markets fail to value, or accurately value, environmental goods and services which lead in turn to environmental concerns being accorded insufficient consideration in everyday market activities. ${ }^{10}$ Where this occurs, there is a strong rationale for some form of government intervention through which the institutions operating in the market can be influenced and encouraged to practice more efficient resource use and/or mitigate the environmental externalities caused by their activities.

$\mathrm{MBI}$ seek to alter the relative prices that individuals and companies face in the provision and use of environmental goods and services and, accordingly, potentially impact on the decisions made in relation to them. The nature, type and design of $\mathrm{MBI}$ can support and discourage certain values and behaviour, thereby playing an important role in helping to ensure that economic growth and development are sustainable and that activities that impose high social and economic costs in environmental terms are discouraged. Therefore, in addition

7 An 'environmentally-related tax' is defined as 'a tax whose base is physical unit that has a proven specific negative impact on the environment'. National Treasury Market-Based Instruments: Draft Policy Paper 2006 at 3.

8 A 'levy' is defined as a 'compulsory statutorily prescribed payment'. National Treasury Market-Based Instruments: Draft Policy Paper 2006 at 5.

$9 \mathrm{Ibid}$. A 'user-charge' is defined as a 'requited payment for a specific service rendered'.

10 For a summary of these market failures see National Treasury Market-Based Instruments: Draft Policy Paper 2006 at 42. 
to raising revenue, they can achieve other objectives, namely to mould human behaviour, encourage more efficient resource use and improve actual environmental outcomes.

The use of $\mathrm{MBI}$ is viewed by many commentators as a more viable way to achieve effective environmental management in that they: are more efficient, flexible and equitable; potentially decrease costs of administration, compliance and enforcement; encourage voluntary initiatives and innovation; encourage people to go beyond regulatory standards and cure market failure to account for the use of natural resources. ${ }^{11}$ As a result of these perceived benefits, developed nations such as Australia, ${ }^{12}$ Canada, $^{13}$ the United States of America $^{14}$ and countries forming part of the European Union ${ }^{15}$ have recently implemented various $\mathrm{MBI}$ in contexts ranging from land-use management and planning, natural resource conservation and pollution and waste management control. These initiatives are spreading to developing nations including: Poland; ${ }^{16}$ Pakistan; ${ }^{17}$ Namibia; ${ }^{18}$ Kenya, Costa Rica; ${ }^{19}$ Brazil and Guatemala ${ }^{20}$ and various other countries in Latin America and the Caribbean. ${ }^{21}$

International environmental conventions and domestic policy documents make reference to the crucial role $\mathrm{MBI}$ can play in facilitating environmental management. South Africa is currently signatory to four such conventions, namely the Convention on Biological Diversity, ${ }^{22}$ the Convention on Wetlands of International Importance Especially as Waterfowl Habitats, ${ }^{23}$ the Stockholm

11 See the authorities listed in $\mathrm{n} 2$ supra.

12 James Environmental Incentives.

13 Wilkie Natural Capital Incentives.

14 Bowles et al 1998 DELPF 209; and Dechert and Smith 1988 HLR 935.

15 Milne et al (eds) Critical Issues in Environmental Taxation 2.

16 Adamson et al Energy.

17 Faruqee Economic Policy.

18 Ashley Incentives Affecting Biodiversity Conservation.

19 World Bank Mainstreaming Market-Based Instruments. See further Blignaut and Anderson 2002 SAJEMS 297.

20 ELI Legal Tools and Incentives.

21 Huber et al Market-based Instruments for Environmental Policymaking.

22 Convention on Biological Diversity (31) ILM 818. See a 11.

23 Convention on Wetlands of International Importance Especially as Waterfowl Habitats (22) ILM 698. See Res VIII.23, par 3, 4, 7 and 8. 
Convention on Persistent Organic Pollutants, ${ }^{24}$ and the United Nations Convention to Combat Desertification in Those Countries Experiencing Serious Drought and/or Desertification. ${ }^{25}$ Reference can also be found in regional arrangements such as the Revised African Convention on the Conservation of Nature and Natural Resources which, although yet to be ratified, should guide future regional environmental policy. ${ }^{26}$

Domestically, government has been considering the potential of using MBI as tools for environmental management in South Africa for a number of years, the outcome of which has been the publication of many research reports and policy documents including: the Environmental Resources Economics Discussion Document Three, ${ }^{27}$ the Katz Commission of Inquiry into Certain Aspects of the Tax Structure of South Africa, ${ }^{28}$ the Market-Based Instruments to Support Environmental Fiscal Reform in South Africa: A Discussion Document, ${ }^{29}$ the White Paper on Environmental Management, ${ }^{30}$ the White Paper on Biodiversity, ${ }^{31}$ the National Biodiversity Strategy and Action Plan ${ }^{32}$ and recently, the National Treasury's Budget Tax Proposals (2005/2006). ${ }^{33}$ The most contemporary statement of government policy in this regard is the Draft Policy Paper released by the National Treasury in April 2006 which contains a detailed theoretical and practical overview of the current and possible future use of MBI to support environmental fiscal reform ${ }^{34}$ in South Africa.

24 Stockholm Convention (40) ILM 532. See art 13.

25 Convention to Combat Desertification (33) ILM 1328. See a 18(1)(e) and 20(2)(d).

26 African Convention http://www.intfish.net/treaties/africa2003.htm. See a 13(2)(b), 17(3) and 19(2). See also revised and related portable document formats online available at http://www.iucn.org/themes/law/pdfdocuments.

27 Deloitte and Touche Environmental Resource Economics.

28 Katz et al Interim Report 88.

29 National Treasury Market-Based Instruments: Discussion Document 2003.

30 White Paper on Environmental Management Policy for South Africa 1998 at 32, 53, 77 and 81. GN 749, GG 18894 of 1998.

31 White Paper on the Conservation and Use of South Africa's Biodiversity 1997. GN 1095, GG 18163 of 1997. See specifically ch 3: Goal 5.

32 DEAT National Biodiversity Strategy 2005 at 29-32, 40-41, 49, 62 and 64.

33 National Treasury 2005/2006 Budget Tax Proposals 200516.

34 'Environmental fiscal reform' refers to the interface between fiscal policy and environmental policy and in broad terms is concerned with the way government revenue raising strategies and expenditure programmes impact on the environment. See National Treasury Market-Based Instruments: Draft Policy Paper 2006 at 2. 


\section{The current use of market-based instruments in South Africa}

South Africa has introduced various environmentally-related taxes and charges which currently account for approximately ten per cent of total tax revenue. ${ }^{35}$ These are listed in the Draft Policy Paper $^{36}$ and include: transport fuel levies; ${ }^{37}$ vehicle taxes; ${ }^{38}$ aviation taxes; ${ }^{39}$ waste taxes and charges; ${ }^{40}$ electricity levies and charges; ${ }^{41}$ mining rehabilitation funds ${ }^{42}$ and water supply charges and levies. ${ }^{43}$ The primary purpose for introducing these was revenue generation and not environmental management. However, owing to the fact that their tax base is a physical unit which has a proven negative impact on the environment

35 National Treasury Market-Based Instruments: Draft Policy Paper 2006 at 38.

36 See for a comprehensive discussion National Treasury Market-Based Instruments: Draft Policy Paper 2006 at 33-38.

37 Petrol, diesel and biodiesel are classified as fuel levy goods in terms of the Customs and Excise Act 91 of 1964 and are accordingly subject to various fuel taxes and levies such as the: General Fuel Levy (used to fund Government expenditure programmes); Road Accident Fund Levy (used to fund the operation of the Road Accident Fund); Equalisation Fund Levy (used to smooth retail fuel prices in times of significant price shocks); and a Customs and Excise Levy (used as a source of funding for the member countries of the South African Customs Union).

38 Vehicles are subject to two levies namely: a customs and excise duty is charged on all passenger and light commercial vehicles in terms of the Customs and Excise Act 91 of 1964; and provincial road licensing fees charged on all vehicles according to their weight under the Road Traffic Act 29 of 1989.

39 Three separate charges are imposed on the aviation industry none of which take environmental considerations into account. First, an aviation fuel levy is imposed in terms of the South African Civil Aviation Authority's Levies Act 41 of 1998 on all aviation fuel that is manufactured, distributed, imported or sold in South Africa. Second, various airport charges are imposed under the above law on aircraft operators and passengers such as landing charges, parking charges, passenger service charges. Thirdly, passenger departure taxes are levied under the Customs and Excise Act 91 of 1964.

40 The only current waste-product tax in South Africa is the excise tax on plastic shopping bags introduced in terms of agreement entered into between the government and organised business and labour in 2004. Local government do, however, levy charges for refuse collection which are effectively aimed at recovering cost incurred in collecting refuse and operating waste disposal facilities.

41 A complex scheme of electricity tariffs are imposed nationally and locally under an array of laws such as the Electricity Act 41 of 1987 and the Local Government Transition Act 209 of 1993.

42 In terms of the Minerals and Petroleum Resources Development Act 28 of 2002, mining companies are responsible for rehabilitating mining sites and making financial provision for such rehabilitation by, for example, establishing dedicated trust funds. The Income Tax Act 34 of 1953 makes provision for establishing funds of this nature and allows fund contributions to be deducted for income tax purposes.

43 The Department of Water Affairs and Forestry (DWAF) has developed a comprehensive Pricing Strategy for Water Use Charges, (1999, under the National Water Act 36 of 1998), relating to the use of raw water, water supplied in bulk by water boards and local authorities and water distributed to end users. The pricing strategy includes water resource management charges, water resource development and use of water works charges, Water Research Commission charges and local municipal water provision tariffs. 
(mainly pollution), they can strictly be regarded as environmentally-related. Revenue generated by these taxes and charges is not generally earmarked for expenditure on environmental management objectives.

There are, however, certain exceptions to this rule where the imposition of the tax or charge is directly related to achieving an environmental outcome and/or generated revenue is dedicated to achieving such an outcome. Firstly, an incentive exists for manufacturing and using alternate environmentally friendly fuels such as biodiesel in that the general levy for these fuels is rebated by forty percent of the diesel rate. Secondly, water supply charges and levies are generally spent on developing and implementing catchment management strategies, managing water quality and use, water resource protection, water demand management, and on funding catchment management agencies which are responsible for managing the majority of the above tasks. The Department of Water Affairs and Forestry (DWAF) currently also is developing a Waste Discharge Charge System, ${ }^{44}$ the aim of which is to recover the costs associated with different water treatment and water quality management programmes and to provide incentives for water users returning water to a water resource to reduce their pollution loads. Thirdly, the tax incentive currently offered to mining companies in respect of contributions to mining rehabilitation funds is clearly based on facilitating environmental management. Fourthly, the plastic bag levy, although not originally introduced to change consumer consumption of plastic bags, but rather to finance plastic recycling operations, appears to facilitate both environmental objectives. Fifthly, although not listed in the Draft Policy Paper, South Africa's new property tax regime introduced under the Local Government: Municipal Property Rates Act 6 of 2004 provides significant incentives for landowners to contract private or communally-owned land into various forms of protected areas. ${ }^{45}$

44 DWAF Water Quality Management Series 2003.

45 Land formally contracted into special nature reserves, national parks and nature reserves proclaimed under the National Environmental Management: Protected Areas Act 57 of 2003 is generally exempt from property tax. See generally, Paterson 2005 SAJELP 115121. 
The National Treasury acknowledges that although generating revenue, achieving environmental outcomes strongly influenced the design of the majority of current environmentally-related taxes and charges and many of these instruments currently have positive environmental outcomes. ${ }^{46}$ Raising revenue and changing taxpayer behaviour do not appear to be mutually exclusive and the National Treasury recognises that there is great potential to improve the environmental outcomes and behavioural incentives created by current environmentally-related taxes and charges and to introduce new ones. ${ }^{47}$ However, prior to intervening in market relations, government must have a clear rationale for doing so and must be confident that the benefits generated from an intervention outweigh any associated costs. Inherent in this enquiry is an analysis of the underlying source of market failure and a consideration of what form of intervention would be most appropriate. The Draft Policy Paper highlights four main forms of policy intervention, namely: using markets; creating markets; environmental regulation; and engaging civil society. These are comprehensively discussed in the Draft Policy Paper and summarised in Table 1 below. ${ }^{48}$

\begin{tabular}{|c|c|c|c|}
\hline $\begin{array}{l}\text { Using Existing } \\
\text { Markets }\end{array}$ & $\begin{array}{l}\text { Creating New } \\
\text { Markets }\end{array}$ & $\begin{array}{l}\text { Environmental } \\
\text { Regulation }\end{array}$ & $\begin{array}{l}\text { Co-opting Civil } \\
\text { Society }\end{array}$ \\
\hline $\begin{array}{l}\text { - Elimination of } \\
\text { perverse subsidies } \\
\text { - Environmentally- } \\
\text { related taxes } \\
\text { - } \text { Deposit-refund } \\
\text { systems } \\
\text { - User-charges } \\
\text { - Targeted subsidies }\end{array}$ & $\begin{array}{l}\text { - } \text { Property rights } \\
\text { - Tradable permits } \\
\text { - International off- } \\
\text { set systems }\end{array}$ & $\begin{array}{l}\text { - Product standards } \\
\text { - Process standards } \\
\text { - Permitting } \\
\text { - Quotas } \\
\text { - Zoning } \\
\text { - Rehabilitation, } \\
\text { liability and } \\
\text { performance } \\
\text { bonds }\end{array}$ & $\begin{array}{l}\text { - Public } \\
\text { participation } \\
\text { procedures } \\
\text { - Information } \\
\text { disclosure } \\
\text { programmes } \\
\text { - Voluntary } \\
\text { environmental } \\
\text { management } \\
\text { agreements }\end{array}$ \\
\hline
\end{tabular}

Selecting the appropriate form of intervention is often a difficult task and frequently a combination of interventions may be required. The Draft Policy

46 National Treasury Market-Based Instruments: Draft Policy Paper 2006 at 39.

47 Ibid.

48 National Treasury Market-Based Instruments: Draft Policy Paper 2006 at 43-48.

49 Adapted from Table 5, National Treasury Market-Based Instruments: Draft Policy Paper 2006 at 43. 
Paper prescribes certain guidelines for selecting the appropriate form of intervention. $^{50}$ These are, however, very broadly framed as a tailored and stylised solution is likely to be required for each specific environmental objective.

\section{Extending the use of market-based instruments in South Africa}

Within the above context, the Draft Policy Paper outlines various specific tax reform options which the National Treasury is of the opinion could contribute towards meeting both fiscal and environmental objectives. These relate exclusively to revenue-raising environmentally-related taxes and charges and are divided into four main options, namely: reforming existing environmentallyrelated taxes and charges in the transport and solid waste sectors; introducing new environmentally-related taxes in the electricity and waste water sectors; reforming legal aspects of non-environmentally-related taxes with perverse environmental incentives and creating incentives to improve environmental outcomes.

\subsection{Reforming existing environmentally related taxes and charges}

\subsubsection{Transport sector}

Vehicle emissions cause significant environmental externalities as a result of oil spills, refinery and vehicle emissions. Vehicles are powered by fuel and with the exception of the rebate accorded to biodiesel, the general fuel levy is currently not specifically designed to mitigate or account for these externalities. Nonetheless, the price of fuel indirectly operates as an incentive to reduce these externalities as higher fuel taxes tend to discourage the use of private

50 See National Treasury Market-Based Instruments: Draft Policy Paper 2006 at 49-55. Relevant criteria which should be considered in determining which form of intervention is appropriate include: level of government intervention (national, provincial, local); alignment with other policy objectives; impacts on competitiveness; world trade implications; design and administrative considerations; the international experience; and distributional impacts. 
vehicles, encourage the use of public transport, and increase consumerdemand for more fuel-efficient technologies.

There is, however, vast scope for existing environmentally-related taxes and charges to create far more direct incentives in this regard. Three specific options are discussed in the Draft Policy Paper. ${ }^{51}$ First, the introduction of differentiated tax rates for cleaner fuel specifications could encourage the development and use of such fuels, thereby decreasing air pollution. It is proposed that lead replacement petrol be taxed at a higher rate than unleaded petrol to discourage the use of the former. Secondly, existing vehicle excise duties could be reformed to encourage the production and purchase of vehicles using cleaner technologies. Current vehicle excise duties are imposed on new passenger and light commercial vehicles and are based solely on the value of a vehicle. Were these vehicle excise duties linked to environmental criteria such as the use of clean technologies, fuel consumption, fuel type and emission standards, they could facilitate environmental objectives. In addition, medium and heavy commercial vehicles, which generally cause far higher external environmental costs than their passenger and light-weight counterparts, should similarly be subject to any reformed excise duty scheme. Thirdly, provincial transport levies and fees, currently based on the net weight of the vehicle, could similarly be reformed to include environmental criteria such as those discussed above.

\subsubsection{Solid waste}

The Draft Policy Paper considers four broad ways through which environmentally-related taxes and charges can be used to improve waste management practices by minimising production and encouraging recycling and re-use. ${ }^{52}$ First, by taxing a particular product or product component, incentives can be created to reduce the amount of waste generated. Currently, the only environmentally-related product tax is the levy imposed on plastic

51 National Treasury Market-Based Instruments: Draft Policy Paper 2006 at 71-74.

52 National Treasury Market-Based Instruments: Draft Policy Paper 2006 at 75-78. 
shopping bags. However, as has been undertaken in various other jurisdictions, similar product-taxes could be levied on goods such as packaging, tyres, batteries, electronic equipment, fluorescent tubes, paper, glass and cardboard. The main environmental externalities related to these products relate to their disposal rather then their use and imposing product-related taxes on such products holds potential to minimise their production. A second method is to introduce a comprehensive deposit-refund system in terms of which a refundable charge is imposed on certain products at point of sale. Although not providing incentives for waste avoidance or minimisation, they hold potential to encourage the removal of many recyclable products from the disposal stream. Although certain deposit-refund schemes exist in South Africa, ${ }^{53}$ these could be extended to incorporate a range of other products such as batteries, reusable chemical containers, tyres, car bodies and electronic products.

The above two options could be complemented through a third mechanism, namely the imposition of disposal taxes. Discouraging ultimate disposal through the price mechanism potentially encourages alternative waste disposal mechanisms such as waste minimisation, recycling and re-use. The Draft Policy Paper advocates further investigation of the appropriateness of using disposal taxes in South Africa, but warns that their implementation must not create the perverse incentive for people to dispose of waste through illegal channels so as to avoid tax liabilities.

Finally, the way in which tariffs are applied for waste collection services, treatment and disposal can provide strong incentives for waste producers to minimise waste generation. The manner in which local government finance and charge for solid waste services, varies widely in South Africa and generally do not incorporate differential charging relative to the volume and nature of waste collected. $^{54}$ Unifying these approaches and imposing differential tariffs

53 These relate particularly to glass, tin and plastic beverage containers.

54 Current practices range from: basing waste tariffs on land value, income or plot size; imposing no tariffs and funding waste management services through property tax; to usercharges based on the frequency of collection or size of container. 
according to the latter criteria, hold great potential for encouraging waste minimisation, re-use and compositing.

\subsection{New environmentally-related taxes}

\subsubsection{Electricity sector}

Electricity generation in South Africa causes many environmental externalities, the most notable of which is air pollution. ${ }^{55}$ Many countries have imposed taxes on electricity generation, consumption and to a lesser extent, emissions.

The Draft Policy Paper highlights two different potential approaches for using $\mathrm{MBI}$ to regulate this sector: a fuel consumptive tax and a fuel input tax. ${ }^{56}$ The former involves imposing a tax on consumers proportional to their use with the aim of decreasing demand. This approach would, however, appear to be at odds with current governmental policy to increase access and encourage the use of electricity in low-income households. The latter entails imposing a tax on electricity generators relative to fuel inputs thereby encouraging improved fuel conversion efficiency and indirectly reducing harmful emissions. This approach would appear to be more in line with components of government's future energy policy such as: improving energy efficiency; reducing emissions, mitigating climate change; and promoting the use of renewable energy sources. $^{57}$

55 These occur at all points in the life-cycle of electricity production and include natural resource overexploitation; land degradation and the pollution of the land, air, fresh water and marine environments. Over ninety per cent of electricity generation in South Africa is coal-based, accounting for approximately forty per cent of all carbon dioxide emissions in South Africa. National Treasury Market-Based Instruments: Draft Policy Paper 2006 at 17.

56 National Treasury Market-Based Instruments: Draft Policy Paper 2006 at 78-81.

57 This future energy policy is reflected in: White Paper on the Renewable Energy Policy for the Republic of South Africa 2003 (GN 513, GG 26169 of 2004); the White Paper on the Energy Policy for the Republic of South Africa 1998 (GN 3007, GG 19606 of 1998); and the National Energy Bill 2004 (GN 2151, GG 26848 of 2004). See further National Treasury Market-Based Instruments: Draft Policy Paper 2006 at 16-18. 


\subsubsection{Water sector}

Water pricing strategies provide potential key tools for regulating demand for water resources. Entrenching a water pricing strategy that reflects the scarcity value of water provides scope for the creation of incentives to encourage and reward efficient and beneficial resource use and conservation. ${ }^{58}$ Although various pricing strategies previously have been implemented in South Africa, these predominantly operate in the domestic sector which accounts for a relatively small proportion of total water use. ${ }^{59}$ Three general options exist for implementing new $\mathrm{MBI}$ in this regard. Firstly, current water pricing strategies could be refined to incorporate environmental criteria and extended to cover other significant water use sectors such as agriculture, forestry and mining. ${ }^{60}$ Secondly, a system of tradable water use permits could be implemented which, theoretically, would better capture the scarcity value of water and ensure its allocation to the most productive use. ${ }^{61}$ Finally, a waste discharge charge system could be implemented whereby a charge is levied according to the nature, quality and volume of effluent discharged. The Department of Water Affairs and Forestry is currently in the process of developing such a system, one of the express aims of which is to provide incentives for water users returning water back to the water resource to reduce their pollution concentrations. $^{62}$ This system will need to be integrated effectively within the existing system of licensing and water authorisations regulated under the

58 National Treasury Market-Based Instruments: Draft Policy Paper 2006 at 82.

59 Ibid.

60 This option is expressly recognised in the DWAF Draft Pricing Strategy for Raw Water Use Charges 2005 at 25.

61 A system of tradable water permits would involve the allocation of water rights and the implementation of a scheme through which these could be traded. The National Water Act 36 of 1998 appears to already provide the basis for such a system as it allows for the legal transfer of water use licenses and this option is similarly recognised in the DWAF Draft Pricing Strategy for Raw Water Use Charges 2005 at 25.

62 DWAF Water Quality Management Series 2003. Government envisages the imposition of four tiers of charges: tier 1 - basic administrative charges (a flat charge per discharger intended to cover the administrative costs of the system); tier 2 - load-based charges (sliding scale charges imposed on dischargers who exceed a water resources target concentrations; tier 3 and 4 - deterrent charges (sliding scale charges imposed on dischargers who exceed prescribed maximum allowable resource directed values for a particular resource). See further the DWAF Draft Pricing Strategy for Raw Water Use Charges 2005 at 31, which again emphasises the value incentive-based charges can play in reducing the environmental externalities caused by waste-water discharge. 
National Water Act 36 of 1998. The potential of implementing similar charges in the context of atmospheric emissions, effluent discharge into the marine environment and noise pollution also should be explored further.

\subsection{Reforming legal aspects of non-environmentally-related taxes with perverse incentives}

Various current taxes in South Africa create perverse environmental incentives. ${ }^{63}$ Those requiring amendment are specifically identified in the Draft Policy Paper. Firstly, tax deductions granted to the agricultural sector to undertake a limited range of conservation-related activities need to be reconsidered and possibly extended to other sectors and a broader array of activities. ${ }^{64}$ Secondly, the diesel fuel tax refund granted to primary producers and non-road freight operators needs to be reassessed and as a minimum, be extended to fuel used in undertaking conservation activities. ${ }^{65}$ Thirdly, the zerorating for Value-added-tax (VAT) of certain products with extreme negative environmental externalities requires reconsideration. ${ }^{66}$ Finally, opportunities for using South Africa's new property tax regime as a tool for supporting conservation initiatives needs to be explored. ${ }^{67}$

63 Perverse incentives actively encourage the opposite of the desired outcome. Where, for example, the desired outcome is pollution control, a tax benefit that rewards pollution amounts to a perverse incentive.

64 National Treasury Market-Based Instruments: Draft Policy Paper 2006 at 85-87. Farmers can deduct their costs incurred in clearing alien invasive vegetation and preventing soil erosion for income tax purposes. This tax benefit is not available to other landowners and therefore potentially creates the perverse incentive for them to develop land, potentially of high conservation value, in order to secure the tax benefit. It is proposed that similar benefits should be extended to all landowners and that a far wider range of conservation activities qualify for deduction.

65 National Treasury Market-Based Instruments: Draft Policy Paper 2006 at 87. The major beneficiaries of the rebate are currently responsible for a significant proportion of environmental damage and include the following sectors: fishing, coastal shipping, offshore mining, agriculture and forestry. Under the operation of the diesel rebate scheme borderline operations may become viable and expanded to the detriment of wider environmental and conservation objectives.

66 National Treasury Market-Based Instruments: Draft Policy Paper 2006 at 88. These products include pesticides, fertilisers and illuminating paraffin. The zero-rating for VAT effectively promotes their use. Socio-economic imperatives, which underlie their introduction, need to be balanced against environmental imperatives.

67 Ibid. Property tax significantly influences land-use as it directly impacts on the viability of holding or using land for various purposes, such as conservation. Property tax can be 


\subsection{Tax incentives to improve environmental outcomes}

The Draft Policy Paper considers various broad overlapping categories of tax incentives for possible implementation in South Africa, as a means to directly encourage certain activities, including those geared toward achieving environmental outcomes.

\subsubsection{Promoting environmental outcomes through alternate state revenue allocation mechanisms}

The allocation of state resources towards achieving environmental outcomes is a complex issue, particularly in developing countries where other socioeconomic imperatives often prevail over their environmental counterparts. The Draft Policy Paper considers two main alternatives for increasing state expenditure on environmental objectives, namely, environmental funds and earmarking. Environmental funds ${ }^{68}$ can be used as an effective tool to achieve environmental management, but are on the decrease internationally and the National Treasury is of the opinion that where environmental considerations are sufficiently reflected in government's budgeting process, it is difficult to see how environmental funds can offer any value.

An alternate approach is introducing earmarked taxes ${ }^{69}$ which already exist in various non-environmentally-related contexts in South Africa. ${ }^{70}$ The National

used as an incentive for landscape protection where, for example, incentives are offered to landowners to hold land for conservation purposes. Alternatively, the imposition of property tax can lead to landscape degradation where, for example, it makes conservation one of the highest taxed land-uses and compels landowners to increase the economic productivity of their land through cultivation or development. For a full discussion of the issue see Paterson 2005 SAJELP.

68 'Environmental Funds' are financial mechanisms set up to achieve certain environmental objectives and can be structured in many different ways, namely: endowment funds (fund that spends only interest income thereby preserving the capital); sinking funds (fund that spends its entire capital over a fixed period); and revolving funds (fund that receives new income on a regular basis to replenish the initial capital). They are generally funded from state and/or international sources. See generally National Treasury Market-Based Instruments: Draft Policy Paper 2006 at 89-91.

69 An 'earmarked tax' is a tax, all or part of the revenues from which are used to finance a specific activity or programme. National Treasury Market-Based Instruments: Draft Policy Paper 2006 at 66 and 101-103. 
Treasury believes that earmarked taxes are generally not a viable option due to the constraints they impose on the budget process and the rigidities that tend to follow from earmarking which can lead to the inappropriate allocation of resources. In addition, the Draft Policy Paper concludes that international experience has shown that earmarking taxes is almost universally ineffective in raising the level of expenditure on the service for which the tax is earmarked and, therefore, it should not be assumed that earmarking revenue streams will provide straightforward solutions to more complex budgeting problems. However, given the financial crises facing many environmental departments and the general environmental crises facing South Africa, government should seriously re-evaluate its current budget allocations and/or reconsider introducing environmentally-related earmarked taxes to specifically fund environmental objectives, given the apparent success of earmarking in raising revenue in other contexts.

\subsubsection{Rehabilitation funds/guarantees}

The use of rehabilitation funds and guarantees are commonplace internationally and are on the increase in South Africa. ${ }^{71}$ These mechanisms provide a valuable tool for encouraging industry to finance mitigation and minimisation of their environmental externalities. Extending their current implementation in South Africa would appear to be well advised and equitable

70 Various tax revenues are currently earmarked for funding the Unemployment Insurance Fund, Road Accident Fund and Skills Development Fund.

71 Rehabilitation funds and guarantees can take many forms, but generally involve the mandatory setting aside of finances, in the form of dedicated funds or financial guarantees, for the purpose of funding rehabilitation following specific activities. Incentives, in the form of tax deductions, are commonly allowed in respect of the quantum of any resources allocated to the fund or guarantee. They are expressly recognised in three laws. Companies, societies, associations or trusts established with the sole objective of complying with the legal obligations imposed on mining operations under the Minerals and Petroleum Resources Development Act 28 of 2002 to rehabilitate disturbances of the surface of the land, prevent pollution and protect the surface of the land and water resources can be deducted for tax purposes in terms of the Income Tax Act 34 of 1953. In addition, the National Environmental Management Act 107 of 1998 environmental impact assessment (EIA) regime (see s $24(5)(d)$ ) and the licensing provisions under the National Water Act 36 of 1998 (see s 30) make express provision for financial security to ensure compliance with statutory obligations. 
as has been recognised in the National Treasury's 2005/2006 Budget Tax Proposals. $^{72}$

\subsubsection{Accelerated depreciation allowances}

Accelerated depreciation allowances schemes ${ }^{73}$ already operate in various contexts in South Africa. ${ }^{74}$ These schemes could be extended to operate as incentives to encourage the adoption and use of pollution abatement technology in the production process or where the adoption of certain technologies is statutorily prescribed to alleviate the financial burden on the companies concerned. It is interesting to note that these sentiments are reiterated in the National Treasury's 2005/2006 Budget Tax Proposals which make specific reference to allowing accelerated depreciation allowances for investments in the production of sustainable energy sources, such as solar energy and windmill technology. ${ }^{75}$

\subsubsection{Revision of specific tax provisions to encourage conservation}

Finally, it is recognised that individuals, communities and companies are integral players in conserving South Africa's rapidly depleting natural resources but that few incentives exist which encourage them to do so. The Draft Policy Paper therefore considers a range of amendments to existing tax provisions

72 National Treasury 2005/2006 Budget Tax Proposals 2005 at 16. Although these proposals only recognise their potential extension to the chemical and electricity generation sectors, similar benefits could be accorded to individuals and/or organisations compelled to undertake a range of environmental management measures such as: complying with the duty of care provisions imposed by the National Environmental Management Act 107 of 1998 s 28, and the National Water Act 36 of 1998 s 19 and/or complying with alien invasive vegetation clearing obligations prescribed under regulations promulgated under the Conservation of Agricultural Resources Act 43 of 1983 (see GNR 1048, GG 10029 of 1984).

73 Costs incurred in acquiring fixed assets such as buildings and machinery are generally capitalised and written-off for tax purposes over the life of the asset. In many countries, however, taxpayers are allowed to write-off the value of the fixed asset over a much shorter time period thereby affording taxpayers a significant financial benefit.

74 See National Treasury Market-Based Instruments: Draft Policy Paper 2006 at 93-94. Accelerated depreciation allowances are currently applied to encourage business activity in various sectors such as mining, agriculture and manufacturing. The majority of these were not introduced on the basis of environmental considerations. One exception is the accelerated depreciation allowance for capital investments in biodiesel and bio-fuels.

75 National Treasury 2005/2006 Budget Tax Proposals 200516. 
which would potentially encourage individuals, communities and companies to play a more active role in this regard. These are exceptionally broad in their ambit and include extending: the range of conservation organisations qualifying for income tax deductions in respect of income received or accrued by them; the value and range of donations to conservation organisations and activities which are tax deductible; the value and range of donations to conservation causes which are exempt from donations tax and the value and range of property transfers fostering conservation which are exempt from transfer duty and estate duty. ${ }^{76}$ Given that the efforts of private individuals and conservation organisations could reduce the burden on government significantly to fund and implement an array of conservation activities, these proposals should receive serious consideration.

\section{Conclusion}

The release of the Draft Policy Paper is a significant development in the context of environmental regulation. It reflects a clear recognition on the part of government of the potential complementary value that $\mathrm{MBI}$ offer to the traditional command-and-control approach. However, like all tax-related instruments, the proposals set out in the Draft Policy Paper will need to conform to generally accepted principals of good taxation, particularly the principles of efficiency, equity, certainty, simplicity and cost minimisation. ${ }^{77}$ Additional criteria which need to be used in evaluating the viability of the proposals include: environmental effectiveness; ${ }^{78}$ tax revenue; ${ }^{79}$ support for the tax; ${ }^{80}$ legislative aspects; ${ }^{81}$ technical and administrative issues; ${ }^{82}$ competitiveness effects; ${ }^{83}$

76 National Treasury Market-Based Instruments: Draft Policy Paper 2006 at 95-100. For a full discussion of these tax reform options see Paterson 2005 SALJ.

77 These principles are comprehensively discussed in the National Treasury Market-Based Instruments: Draft Policy Paper 2006 at 56-64.

78 The tax should be related and well targeted to achieving a clear environmental objective.

79 The level of tax revenue generated and the way in which this revenue will be used need be clarified.

80 All relevant stakeholders must be canvassed in developing any tax proposals.

81 Necessary fiscal and environmental legal reform must be clarified and aligned, and compliance with international trade instruments ensured. 
distributional impacts; ${ }^{84}$ and adjoining policy areas. $^{85}$ Balancing these numerous and often conflicting criteria will not be easy - a process further complicated by the uncertainties associated with determining the value of numerous relevant aspects such as: environmental externalities; environmental goods and services as well as various socio-economic and environmental outcomes which may flow from their implementation. Although the Draft Policy Paper provides no guidance on how to prioritise the above criteria and determine these values, it nonetheless does present an important framework within which possible tax reform options can be evaluated. ${ }^{86}$ When seeking to design and implement the proposals, government would be well advised to draw from the wealth of foreign experience in implementing similar mechanisms. Aligning and coordinating the roles and responsibilities of the different national, provincial and local authorities in this process, together with the policies and laws they administer, appears to be a further prerequisite for success. In addition, constructively engaging the private and corporate sectors within this process would similarly appear to be essential to ensure their understanding and potential buy-in to the system.

Nonetheless, it must be remembered that $\mathrm{MBI}$ are but one of the alternative regulatory interventions available to government. Others include, for example, co-opting civil society participation and creating markets for environmental goods and services. Selecting between these different interventions is a complex process and is often dependant on specific contextual circumstances such as the nature of the market failure and the economy involved. No one approach is necessarily better than another and it is generally accepted that a

82 The tax base should be close to the environmental objective, and the tax rate set according to the level of externality and procedures put in place to minimise tax avoidance, tax evasion, compliance and collection costs.

83 The impact of the tax on domestic industries and other aspects of the economy such as employment, inflation and international competitiveness need to be considered and mitigated through mechanisms such as reduced tax rates, tax ceilings, tax refunds and tax shifting options.

84 The impact of the proposed tax in different income groups must be assessed and mitigated where necessary to ensure equity.

85 The tax reform must be aligned with other relevant tools such as environmental regulatory frameworks and voluntary schemes.

86 National Treasury Market-Based Instruments: Draft Policy Paper 2006 at 41-64. 
mixed approach needs to be adopted. ${ }^{87}$ The $\mathrm{MBI}$ proposed in the Draft Policy Paper should, therefore, not be used to replace any current command-andcontrol and other measures, but rather to complement them and any future alternate regulatory interventions and incentives introduced by government.

87 National Treasury Market-Based Instruments: Draft Policy Paper 2006 at i. 


\section{Bibliography}

Adamson et al Energy

Adamson S et al "Energy Use, Air Pollution and Environmental Policy in

Krakow: Can Economic Incentives Really Work?" 1996 World Bank

Technical Paper No 308

Ashley Incentives Affecting Biodiversity Conservation

Ashley C Incentives Affecting Biodiversity Conservation and Sustainable

Use: The Case of Land Use Options in Namibia (Directorate of

Environmental Affairs Namibia 1996)

Blignaut and Anderson 2002 SAJEMS

Blignaut $\mathrm{J}$ and Anderson $\mathrm{H}$ "The Integration of Economics and the Environment through Incentives: An Overview of the Costa Rican Success

Story" 2002 5(2) South African Journal of Economic and Management Sciences 297

Bowles et al 1998 DELPF

Bowles I et al "Economic Incentives and Legal Tools for Private Sector

Conservation" 1998(8) Duke Environmental Law and Policy Forum 209

Bruce and Ellis Environmental Taxes

Bruce N and Ellis G "Environmental Taxes and Policies for Developing

Countries" 1993 World Bank Policy Research Working Paper No WPS1177

DEAT National Biodiversity Strategy 2005

Department of Environmental Affairs and Tourism South Africa's National

Biodiversity Strategy and Action Plan (Government Printers 2005)

Dechert and Smith 1988 HLR

Dechert WD and Smith JL "Environmental Liability and Economic Incentives for Hazardous Waste Management" 1988(25) Houston Law Review 935-942 
Deloitte and Touche Environmental Resource Economics

Deloitte and Touche Consortium of Consultants Environmental Resource Economics Discussion Document Three - The Proposed Method for the Introduction of Economic Instruments as Tools of Environmental Management in South Africa (DEAT Pretoria 1996)

DWAF Draft Pricing Strategy for Raw Water Use Charges 2005

Department of Water Affairs and Forestry Draft Pricing Strategy for Raw Water Use Charges in GN 1045 Government Gazette 27732 of 1 July 2005

DWAF Pricing Strategy for Water Use Charges 1999

Department of Water Affairs and Forestry Pricing Strategy for Water Use Charges (Government Printers 1999)

DWAF Water Quality Management Series 2003

Department of Water Affairs and Forestry Water Quality Management Series Sub-Series No MS 11 "Towards a Strategy for a Waste Discharge Charge System" $1^{\text {st }}$ ed (Government Printers 2003)

\section{ELI Legal Tools and Incentives}

Environmental Law Institute Legal Tools and Incentives for Private Lands Conservation in Latin America: Building Models for Success (ELI Washington 2003)

Faruqee Economic Policy

Faruqee $\mathrm{F}$ "Using economic policy to improve environmental protection in Pakistan" 1997 World Bank Policy Research Working Paper No WPS1757

Henderson 1994 SAJELP

Henderson P "Fiscal incentives for Environmental Protection - Introduction" 1994(1) South African Journal of Environmental Law and Policy 49

Huber et al Market-based Instruments for Environmental Policymaking Huber R et al "Market-based Instruments for Environmental Policymaking in 
Latin America and the Caribbean - Lessons from Eleven Countries" 1998 World Bank Discussion Paper No WDP381

James Environmental Incentives

James D "Environmental Incentives: Australian Experience with Economic Instruments for Environmental Management" 1997 Environmental Economics Research Paper No 5

Katz et al Interim Report

Katz MM et al Interim Report of the Commission of Inquiry into Certain Aspects of the Tax Structure of South Africa (Republic of South Africa Government Printer Pretoria 1994)

Milne et al (eds) Critical Issues in Environmental Taxation Milne $\mathrm{J}$ et al (eds) Critical Issues in Environmental Taxation Volume I: International and Comparative Perspectives (Richmond Law \& Tax Richmond 2003)

National Treasury 2005/2006 Budget Tax Proposals 2005 National Treasury 2005/2006 Budget Tax Proposals (Government Printers 2005)

National Treasury Market-Based Instruments: Draft Policy Paper 2006 National Treasury A Framework for Considering Market-Based Instruments to Support Environmental Fiscal Reform in South Africa - Draft Policy Paper (Government Printers 2006)

National Treasury Market-Based Instruments: Discussion Document 2003 National Treasury Market-Based Instruments to Support Environmental Fiscal Reform in South Africa: a Discussion Document (Government Printers 2003)

Paterson 2005 SAJELP

Paterson A "Property Tax a Friend or Foe for Landscape Protection in 
South Africa" 2005 (12) South African Journal of Environmental Law and Policy 97

Paterson 2005 SALJ

Paterson A "Tax Incentives - Valuable Tools for Biodiversity Conservation in South Africa" 2005 (122) South African Law Journal 182

Pearce, Markandya and Barbier Blueprint for a Green Economy

Pearce D, Markandya A and Barbier E Blueprint for a Green Economy (Earthscan London 1989)

Stauth and Baskind Resource Economics

Stauth R and Baskind P "Chapter 3: Resource Economics" in Fuggle RF and Rabie MA (eds) Environmental Concerns in South Africa: Technical and legal perspectives (Juta Cape Town 1983)

Westin Understanding Environmental Taxes

Westin R “Understanding Environmental Taxes” Unpublished paper (1992)

Wilkie Natural Capital Incentives

Wilkie $\mathrm{K}$ What is in it for me?: Exploring Natural Capital Incentives (Canada West Foundation Calgary 2005)

World Bank Mainstreaming Market-Based Instruments World Bank "Costa Rica - Mainstreaming Market-Based Instruments for Environmental Management Project" 2006 World Bank Project Appraisal Document Report No 6084

\section{Register of international and regional instruments}

Convention on Biological Diversity (31) ILM 818

Convention on Wetlands of International Importance especially as Waterfowl Habitat (11) ILM 963-976 (Ramsar convention 1972) 
Revised African Convention on the Conservation of Nature and Natural Resources 2003

Stockholm Convention on Persistent Organic Pollutants (40) ILM 532

(Stockholm Convention 2004)

United Nations Convention to Combat Desertification in Those Countries

Experiencing Serious Drought and/or Desertification (33) ILM 1328

(Convention to Combat Desertification 1996)

\section{Register of legislation}

Conservation of Agricultural Resources Act 43 of 1983

Constitution of the Republic of South Africa, 1996

Customs and Excise Act 91 of 1964

Electricity Act 41 of 1987

Genetically Modified Organisms Act 15 of 1997

Government Gazette no 10029 of 25 May 1984

Government Gazette no 18163 of 28 July 1997

Government Gazette no 18894 of 15 May 1998

Government Gazette no 19606 of 17 December 1998

Government Gazette no 20615 of 12 November 1999

Government Gazette no 26169 of 14 May 2004

Government Gazette no 26848 of 8 October 2004

Government Gazette no 27732 of 1 July 2005

Income Tax Act 34 of 1953

Local Government Transition Act 209 of 1993

Local Government: Municipal Property Rates Act 6 of 2004

Marine Living Resources Act 18 of 1998

Minerals and Petroleum Resources Development Act 28 of 2002

National Environmental Management Act 107 of 1998

National Environmental Management Amendment Act 8 of 2004

National Environmental Management: Air Quality Act 39 of 2004

National Environmental Management: Biodiversity Act 10 of 2004

National Environmental Management: Protected Areas Act 57 of 2003 
National Forests Act 84 of 1998

National Water Act 36 of 1998

Road Traffic Act 29 of 1989

South African Civil Aviation Authority's Levies Act 41 of 1998

\section{List of website URLs}

African Convention (text)

http://www.intfish.net/treaties/africa2003.htm

African Convention (revised and related documents)

http://www.iucn.org/themes/law/pdfdocuments

Convention on Biological Diversity

http://www.jus.uio.no//m/biological.diversity.convention.1992/doc

Convention to Combat Desertification

http://www.unccd.int/convention/text/convention.php

Ramsar Convention

http://www.ramsar.org/

Stockholm Convention

http://eur-lex.europa.eu/LexUriServ/site/en/oj/2006/l 209// 20920060731

en00030029.pdf

\section{List of abbreviations}

a article(s)

CCD Convention to Combat Desertification

DEAT Department of Environmental Affairs and Tourism

DWAF Department of Water Affairs and Forestry

EIA environmental impact assessment

ELI Environmental Law Institute

$\mathrm{MBI} \quad$ market-based instruments

NEMA National Environmental Management Act

NEMBA National Environmental Management: Biodiversity Act

NEMPAA National Environmental Management: Protected Areas Act 
NFA National Forests Act

NWA National Water Act

$\mathrm{S}$ section

VAT Value-added-tax 